\title{
KONDISI SOSIAL-EKONOMI MASYARAKAT YANG BERTEMPAT TINGGAL DI BANTARAN SUNGAI MENTAYA
}

\author{
Akbar Hidayat \\ Email: akbarhidayat3203@gmail.com \\ Program Studi Pendidikan Sejarah Fakultas Keguruan dan Ilmu Pendidikan \\ Universitas Lambung Mangkurat \\ Banjarmasin
}

\begin{abstract}
Abstrak
Tulisan ini menjelaskan atau menggambarkan bagaimana kehidupan masyarakat yang berada di bantaran sungai mentaya baik dari sisi sosial masyarakatnya maupun ekonomi mereka yang terletak di kota sampit provinsi Kalimantan tengah, Indonesia, Dalam Bahasa Dayak Ot Danum, Sungai Mentaya itu disebut batang danum kupang bulan. Sungai Mentaya ini merupakan sungai utama dan dimanfaatkan sebagai prasarana perhubungan di Sampit. Sungai Mentaya merupakan sungai kebanggan masyarakat Sampit karena luas dan panjangnya sungai mentaya, sehingga Sampit bisa di sebut dengan sebutan Kota Mentaya.
\end{abstract}

\section{PENDAHULUAN}

Sejarah menunjukkan adanya keterkaitan erat antara permukiman dan sungai, terutama pada daerah-daerah, Menurut Anis (2015:57) Sumber sejarah berasal dari jejak atau kesaksian yang ditinggalkan dalam peristiwa, Kemudian ditafsirkan oleh sejarawan sehingga dapat menceritakan tentang realitas masa lalu. Sejarah berupaya menjelaskan kebenaran, keadaan yang sebenarnya melalui metode dan metodeloginya (Anis, 2013:155). Kalimantan yang telah memiliki hubungan yang sangat dekat antara sungai dalam pembentukan dan perkembangan perkotaan dan masyarakatnya. Dari perkembangan waktu masyarakat yang bermukim di bantaran sungai, mereka dapat menjadikan sungai sebagai salah satu sumber kebutuhan hidup dan sumber penghasilan mereka. Dengan adanya interaksi masyarakat dan sungai, maka terbentuklah budaya sungai. Secara kultur masyarakat Kota Sampit sangat dekat dengan sungai dan sulit dipisahkan dengan sungai. Bahkan dari sejarah yang ada, cikal 
bakal Kota Sampit merupakan sebuah kerajaan di tepi sungai atau bermula dari permukiman bantaran sungai. Tidak salah jika permukiman di tepi sungai merupakan salah satu ciri khas Kota Sampit, Munculnya kota selalu dikaitkan dengan peradaban (porda dkk, 2013:14). Bantaran Sungai Mentaya dimanfaatkan untuk berbagai aktivitas, dari aktivitas permukiman maupun aktivitas lainnya. Sungai mentaya pun memiliki peran yang sangat penting di kota sampit oleh karena itu menarik jika kita dapat membahas sebuah kehidupan dari bantaran sungai mentaya ini baik dari kondisi sosial maupun ekonomi masyarakatnya.

\section{KONDISI EKONOMI MASYARAKAT DI BANTARAN SUNGAI MENTAYA}

Aliran Sungai Mentaya memiliki fungsi yang penting dalam mendukung perkembangan perekonomian. Daerah yang dilalui sungai dapat dijadikan prasarana transportasi sungai. Sungai Mentaya yang menjadi pusat jasa transportasi sungai dapat menjadi suatu usaha untuk menambah penghasilan ekonomi. Baik untuk pemerintah maupun masyarakatnya. Sungai Mentaya menjadi pusat jasa transportasi sungai dan produksi hasil ikannya yang dapat menambah nilai penghasilan atau masukan. Seperti dijelaskan sebelumnya terkait masa jaya transportasi sungai ditahun 1970-1980, pendapatan pemilik klotok dapat mencapai Rp 4.000/perharinya dengan koversi emas pada saat tersebut dalam kisaran Rp 1.000 pergram, maka pendapat tersebut masa sekarang adalah kurang lebih 4jt/perminggunya. Dalam segi perdagangan, bantaran sungai memiliki 2 pasar yang berada di bantaran sungai, 1 pasar dengan skala kelurahan dan 1 pasar dengan skala kota, membuat arus barang dagangan ramai melewati Sungai Mentaya. Dengan segala fungsi bantaran sungai mulai dari transportasi (dilengkapi dengan batang sebagai sarana sandar klotok) dan dekat dengan sumber air, maka pada masa tersebut mempunyai rumah di bantaran sungai merupakan sesuatu hal yang sangat elit dan mahal. Sehingga mayoritas masyarakat yang tinggal di bantaran sungai adalah masyarakat menegah keatas atau kaya.

Akan tetapi perkembangan pembangunan ke darat dan pergeseran kegiatan transportasi membuat kondisi masyarakat terbalik, mayoritas masyarakat yang ada di bantaran sungai menjadi masyarakat golongan menengah ke bawah. Pergeseran status sosial ini juga terjadi karena ketidak siapan masyarakat lokal dalam menghadapi pergeseran fungsi ekonomi dari Sungai Mentaya. Kegiatan budaya tahunan yang memiliki nilai ekonomi yang 
cukup mempengaruhi adalah mandi safar. Kegiatan mandi safar berhasil membuat kegiatan ekonomi sesaat di sekitar acara kawasan. Menjadi kegiatan budaya sungai tahunan yang tersisa di Sungai Mentaya, menjadikan animo masyarakat terhadap kegiatan ini sangat tinggi sehingga memunculkan pedagang dadakan musiman dan mandi safar ini adalah bagian dari sebuah budaya sejarah lokal dikota sampit.

\section{KONDISI SOSIAL MASYARAKAT DI BANTARAN SUNGAI MENTAYA}

Wujud fisik suatu kota terbentuk akibat pertumbuhan dan perkembangan segenap kegiatan pekotaan, baik kegiatan sosial, ekonomi, budaya maupun politik (Wilianto, 1992). Hal tersebut menunjukkan bahwa bahwa fisik kota dapat menjadi indikasi untuk melihat kondisi kehidupan dari masyarakat kota setempat. Bentuk fisik suatu kota akan mempengaruhi aktivitas masyarakatnya begitu juga aktivitas masyarakat dapat mempengaruhi bentuk fisik suatu kota. Kemampuan adaptasi masyarakat dari segi sosial budaya dengan masyarakat lokal sangatlah bagus terlebih dalam pergaulan dan interaksinya (Syarifuddin 2019:418). Kegiatan masyarakat akan menciptakan elemen fisik yang dapat memunculkan kembali reaksi masyarakat terhadap fisik lingkungan yang ditinggalinya. Nilai-nilai sosial terdapat dalam hubungan dengan penggunaan tanah, yang dapat berhubungan dengan kebiasaan, sikap moral, pantangan, pengaturan pemerintah, peninggalan budaya, dan pola tradisional (Chapin, 1972). Dapat ditarik kesimpulan bahwa perilaku masyarakat merupakan suatu tindakan dan sifat manusia dalam tata guna lahan, tindakan dan tingkah laku ini yang disebabkan oleh kebutuhan dan keinginan manusia untuk berlaku baik dalam kehidupan sosial di lingkungan dan dalam memenuhi keinginan ekonomi. Kebutuhan dan keinginan yang berlaku dalam kehidupan manusia akan memberikan pengaruh terhadap nilai-nilai yang terkandung dalam aspek kehidupan.

\section{SIMPULAN}

Manusia dan sungai merupakan sebuah kesatuan mengapa demikian karena pada dasarnya manusia tidak bisa lepas dari yang namanya sungai karena sungai merupakan sumber kehidupan manusia, pada zaman dahulu sungai digunakan untuk mencari makan maupun yang lainnya manusia pada zaman dahulu tidak bisa lepas dari sungai dan mereka 
membuat rumah atau tempat tinggal di sekitaran sungai hal ini menunjukkan bahwa pentingnya sungai bagi kehidupan ma nusia, dan di kota sampit sendiri sungai mentaya merupakan sumber kehidupan mereka juga dimana sebelum berkembangnya zaman seperti sekarang dahulu masyarakat sangat bergantung pada sungai mentaya dimana mereka memanfaatkan sungai mentaya sebagai mata pencaharian mereka seperti mencari ikan kemudian di jual ke pasar dan menjadikan sungai mentaya sebuah sarana transportasi air yang digunakan pada zaman waktu itu. Kondisi soial mereka pun bergantung pada sungai bagaimana mereka hidup dan berinteraksi dengan masyarakat lain yang ada di sungai tersebut dan mereka yang berada di bantaran sungai mentaya tersebut memiliki karakteristik kehidupan mereka maka dari itu sungai disini kaitannya dengan manusia sangatlah penting namun walaupun demikian sungai yang baik harus di jaga dan jangan dirusak karena sungai merupakan sumber kehidupan.

\section{REFERENSI}

Abbas, E. W. (2013). Mewacanakan Pendidikan IPS. Bandung: WAHANA Jaya Abadi.

Anis, M. Z. (2015). sejarah bukan warisan melainkan pembelajaran. pendidikan sejarah untuk menyiapkan generasi emas indonesia 2050, 53-64.

Belly Rayano, R. W. (2017). Persepsi Masyarakat Bermukim di Tepian Sungai Pemuatan Kecamatan Bamaang, Sampit, Kabupaten Kotawaringin timur. Jurnal Pembangunan Wilayah dan Kota, 369-384.

Chapin. (1972). Perencanaan penggunaan lahan perkotaan. Utrecht: University of Illinois.

Porda Herry, D. (2013). DARI DISTRIK KE KOTA KECAMATAN MENYUSURI JEJAK KOTA SATUI DALAM LINTASAN SEJARAH . Leiden: E. J. Brill, Tahun 1902.

Rahman, B. (2015). HUBUNGAN AKTIVITAS BUDAYA PERMUKIMAN BANTARAN SUNGAI TERHADAP KELESTARIAN FUNGSI SUNGAI. PELESTARIAN KOTA PUSAKA DAN SAUJANA BUDAYA, 377-393.

Syarifuddin, d. (2019). KEMAMPUAN ADAPTASI MASYARAKAT TRANSMIGRAN JAWA DI LAHAN GAMBUT DESA JEJANGKIT TIMUR KECAMATAN JEJANGKIT KABUPATEN BARITO KUALA. EnviroScienteae, 415-419. 
Willianto. (1992). Perancangan Kota. Jakarta: Perancanaan Wilayah dan Kota Edisi Desember. 